\section{Waist circumference and waist circumference to height ratios of Kaingáng indigenous adolescents from the State of Rio Grande do Sul, Brazil}

\author{
Circunferência da cintura e circunferência da \\ cintura/estatura entre adolescentes indígenas \\ Kaingáng do Rio Grande do Sul, Brasil
}

\author{
${ }^{1}$ Faculdade de Enfermagem \\ Universidade Federal de \\ Minas Gerais, Belo Horizonte, \\ Brasil. \\ 2 Instituto de Estudos em \\ Saúde Coletiva, Universidade \\ Federal do Rio de Janeiro, \\ Rio de Janeiro, Brasil. \\ 3 Instituto de Nutrição Josué \\ de Castro, Universidade \\ Federal do Rio de Janeiro, \\ Rio de Janeiro, Brasil. \\ ${ }^{4}$ Faculdade de Saúde \\ Pública, Universidade de \\ São Paulo, São Paulo, Brasil. \\ 5 Departamento de \\ Nutrição, Universidade \\ Federal de Santa Catarina, \\ Florianópolis, Brasil. \\ 6 Faculdade de Medicina, \\ Universidade Federal do Rio \\ Grande do Sul, Porto Alegre, \\ Brasil. \\ Correspondence \\ T. G. Castro \\ Departamento de \\ Enfermagem Materno- \\ Infantil e Saúde Pública, \\ Faculdade de Enfermagem, \\ Universidade Federal de \\ Minas Gerais. \\ Av. Alfredo Balena 190, \\ Belo Horizonte, $M C$ \\ 30130-100, Brasil. \\ tgontijo108@gmail.com
}

\section{Abstract}

The aim of this study was to describe the distribution of waist circumference (WC) and WC to height (WCTH) values among Kaingáng indigenous adolescents in order to estimate the prevalence of high WCTH values and evaluate the correlation between WC and WCTH and body mass index (BMI)-for-age. A total of 1,803 indigenous adolescents were evaluated using a school-based cross-sectional study. WCTH values $>0.5$ were considered high. Higher mean WC and WCTH values were observed for girls in all age categories. WCTH values $>0.5$ were observed in $25.68 \%$ of the overall sample of adolescents. Mean WC and WCTH values were significantly higher for adolescents with BMI/age z-scores $>2$ than for those with normal $z$-scores. The correlation coefficients of WC and WCTH for BMI/age were $r=$ 0.68 and 0.76, respectively, for boys, and $r=0.79$ and 0.80 , respectively, for girls. This study highlights elevated mean WC and WCTH values and high prevalence of abdominal obesity among Kaingáng indigenous adolescents.

Anthropometry; Abdominal Obesity; Indigenous Population; Health of Indigenous Peoples
Teresa Gontijo de Castro ${ }^{1}$

Laura A. Barufaldi 2

Michael Maia Schlüssel 3

Wolney Lisboa Conde 4

Maurício Soares Leite 5

Ilaine Schuch 6

\section{Introduction}

In recent decades, studies have shown a rapid and pronounced increase in the worldwide prevalence of obesity, including child and adolescent obesity, reaching epidemic proportions 1 . Studies have also shown a high prevalence of obesity in indigenous adolescents from certain ethnic groups 2,3,4,5 and have suggested that socioeconomic and cultural transformations resulting from contact with surrounding societies are the main cause $6,7,8$.

In a previous publication 4 , the population of the present study was characterized by a high prevalence of overweight, according to body mass index (BMI)-for-age, and low height/age index values 9 . The prevalence of overweight observed among male and female adolescents was $5 \%$ and $8.6 \%$, respectively. Z-scores lower than -2 for height/age were observed in $21.2 \%$ of male adolescents and in $18.5 \%$ of all adolescents 4

The literature indicates that obesity in adolescence may persist into adulthood, increasing the risk of cardiovascular and metabolic problems; however, consensus remains elusive about the most valid method of identifying overweight/obesity in these individuals 10 . BMI is the most widely used anthropometric method for assessing nutritional status in epidemiological studies due to its simplicity and low cost 11,12. BMI has shown good agreement with adiposity indicators in the diag- 
nosis of overweight and obesity 13 and in assessing the risk of cardiovascular disease 14 . Despite these advantages, the various BMI cut-off points used for diagnosis in empirical studies 9,15,16,17 have made it difficult to determine a baseline reference, and thus a consistent estimate of the magnitude and evolution of obesity.

Abdominal obesity, defined as the excessive accumulation of central subcutaneous and visceral fat, has emerged as an important predictor of metabolic complications and adverse health effects. It has been associated with metabolic syndrome, type 2 diabetes and cardiovascular disease in adults 18,19 , as well as with increased cardiovascular and metabolic risks in children and adolescents $20,21,22$. Furthermore, the association between abdominal obesity and cardiovascular risk appears to hold true regardless of body weight status 23 .

In line with these findings, waist circumference (WC) and waist circumference to height (WCTH) have been proposed as measures of obesity and central adiposity 23 . Studies have shown that these parameters are better predictors of cardiovascular risk than an assessment using BMI alone 19,24. For example, one study of an Australian indigenous population described improvement of cardiovascular risk prediction using measurements of WC and WCTH 25. Using WCTH has a specific advantage over using WC alone, because the height adjustment allows the establishment of a single cut-off point applicable to the general population, regardless of gender, age and ethnicity 22 .

Few studies have evaluated patterns of abdominal obesity in Brazilian indigenous populations or indigenous populations of other countries. Notably, the few available studies have shown that obesity is an increasingly common outcome affecting indigenous adults, adolescents and children 4,26,27. The lack of research on this topic combined with alarming results from existing studies highlights the relevance of the present research in building a broad epidemiological scenario for indigenous populations. The objective of this study therefore was to describe the distribution of WC and WCTH measurements among Kaingáng indigenous adolescents attending schools in the State of Rio Grande do Sul, Brazil in order to determine the prevalence of high WCTH values among adolescents and evaluate the correlation between WC and WCTH and BMI-for-age.

\section{Methods}

This study used a school-based, cross-sectional approach and was conducted in all 35 schools in the Kaingáng Indigenous Territories (ITs) in the State of Rio Grande do Sul whose land tenure had been recognised by the National Indian Foundation (Fundação Nacional do Índio - FUNAI) at the time of data collection. The study population consisted of all adolescents aged between 10 and 19 years 28 enrolled in the schools involved in the project. The Kaingáng people belong to the Macro-Jê linguistic trunk and have been in continuous contact with the non-indigenous population since the eighteenth century. They are one of the largest indigenous populations in the country, with approximately 30,000 individuals distributed throughout 30 ITs in the states of São Paulo, Paraná, Santa Catarina and Rio Grande do Sul 29 recognized by the FUNAI in 2008, of which 12 are located in the State of Rio Grande do Sul. The 35 schools studied are distributed among these 12 ITs: Guarita, Iraí, Monte Caseros, Carreteiro, Ventarra, Nonoai, Cacique Doble, Carreteiro, Inhacorá, Ligeiro, Rio da Várzea and Serrinha.

A team was trained in the indigenous communities prior to data collection between July and December 2008. Information about students' sex and date of birth were obtained directly from school enrolment records. Data collection was conducted at the schools during a period of one to four days (situation observed in seven schools in one of the ITs) depending on the number of students enrolled at the school.

Anthropometric measurements were taken in duplicate, as recommended by the World Health Organization 30 , and mean values were used in the analysis. Weight was assessed in kilograms (kg) using a portable electronic digital scale (Mars; Marte Balanças e Aparelhos de Precisão Ltda., Santa Rita do Sapucaí, Minas Gerais, Brazil, model PP200) with a capacity of $150 \mathrm{~kg}$ and precision of $0.05 \mathrm{~kg}$. Height was measured in centimetres $(\mathrm{cm})$ using an Alturexata stadiometer (Alturexata Ltda., Belo Horizonte, Brazil) with an accuracy of $1 \mathrm{~mm}$ and capacity of $213 \mathrm{~cm}$. WC was assessed using anthropometric inelastic tape (Cardiomed; Cardiomed Ltda., Curitiba, Brazil) with a length of $2 \mathrm{~m}$ and an accuracy of $1 \mathrm{~mm}$. Measurements were taken at the midpoint between the last rib and the iliac crest 31 . BMI was calculated using the following formula: weight/ (height) ${ }^{2} 30$.

Z-scores were calculated for BMI-for-age using the program WHO ANTHRO Plus (Centers for Disease Control and Prevention, Atlanta, USA). Individuals were classified according to BMI-forage in two categories: 1 ) normal (z-scores within -2 and +2$)$ and obesity $(z$-scores above +2$) 9$. Since 
only one individual was underweight (BMI-forage $\mathrm{z}$-score $<-2$ ) this category was excluded from the analysis. WCTH values $>0.5$ were considered high 32,33 .

Double data entry was performed using Epi Info software, version 6.04 (Centers for Disease Control and Prevention, Atlanta, USA). Data was analysed using Stata 10.0 (Stata Corp., College Station, USA). Frequencies were calculated for categorical variables and percentile or mean and standard deviation (SD) for continuous variables. The Student's t-test for Independent Samples and Analysis of Variance (ANOVA) were used to explore the differences between means and proportions were compared using the Chi-square test. Correlations between WC, WCTH and BMIfor-age values were evaluated using Pearson's correlation coefficient. A significance level of $\mathrm{p}<$ 0.05 was adopted for all tests.
This study was approved by the following organisations at all required levels for research with indigenous individuals 34: the Ethics Committee of the Federal University of Rio Grande do Sul (Universidade Federal do Rio Grande do Sul; case $\left.n^{\circ} .2007726\right)$, the National Research Ethics Committee (case $n^{\circ}$. 14,449), the Brazilian National Research Council (Conselho Nacional de Desenvolvimento Científico e Tecnológico - CNPq) and the FUNAI (case no. CGEP/08 1141/08). Only individuals presenting a written or digital Informed and Free Consent Form signed by a parent or guardian were evaluated by this study.

\section{Results}

Figure 1 shows the total number of adolescents enrolled in schools at the time of the study, the

\section{Figure 1}

Description of the study sample.

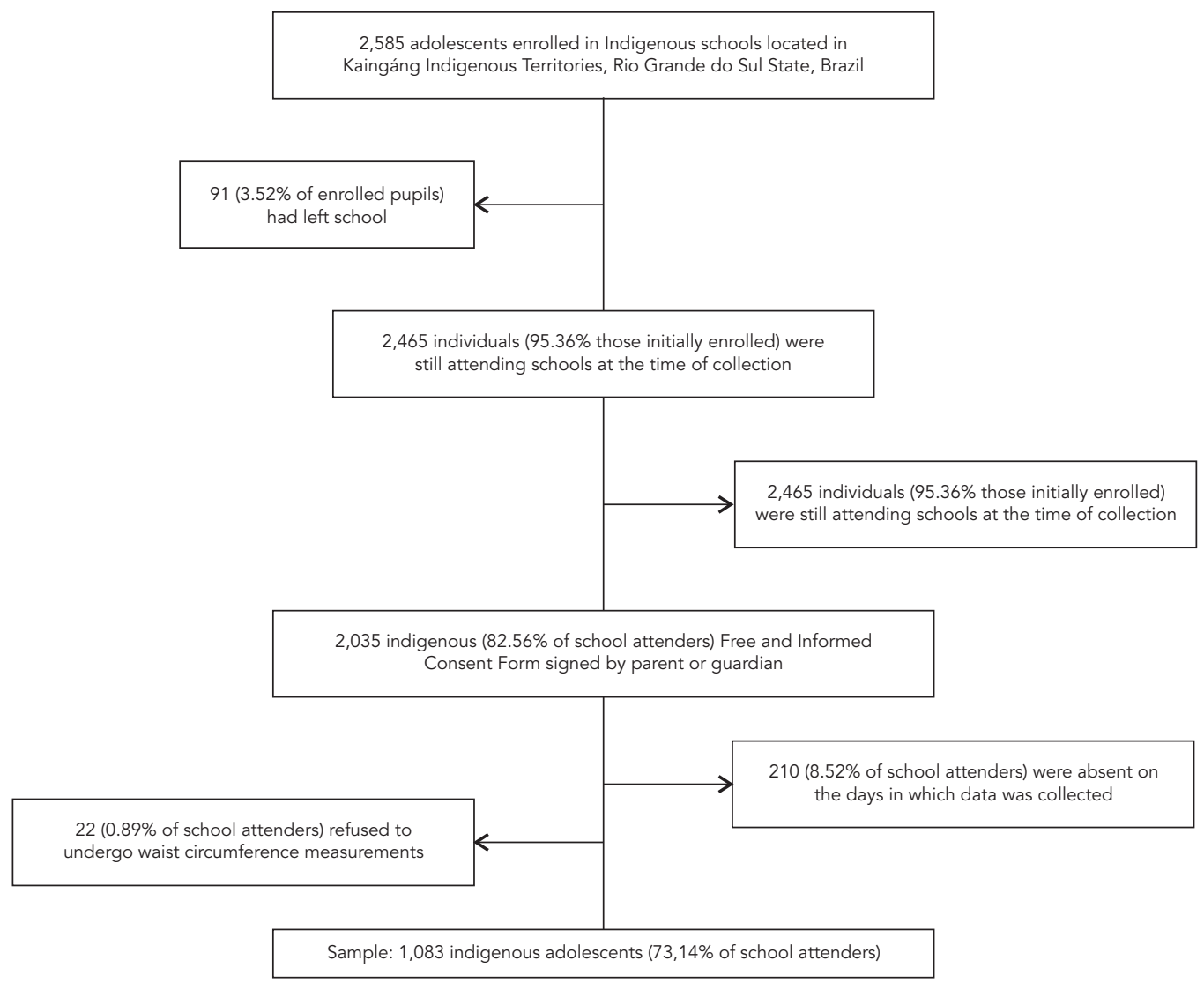


total number of assessed adolescents and also the number of losses, refusals and absences. A total of 1,803 indigenous adolescents were evaluated $(73.14 \%$ of the students enrolled at the time of data collection), of which 931 (51.64\%) were boys. The mean age of the adolescents studied was 12.45 years $( \pm 2.10)$ and the mean age of boys and girls was 12.58 years $( \pm 2.21)$ and 12.32 years $( \pm 1.97)$, respectively. A comparison between evaluated indigenous adolescents and those enrolled in a school but not evaluated yielded no statistically significant difference for sex ratio $\left(\chi^{2}=\right.$ $0.060, \mathrm{p}=0.807$ ); however, the average age was lower $(\mathrm{t}=-9.148, \mathrm{p}<0.0001)$ for evaluated individuals (data not shown).

Table 1 presents the mean, SD, minimum and maximum values, and percentiles 5 (p5) and 90 (p90) forWC and WCTH by sex and age. Mean WC and WCTH values were higher for girls than for boys in all age categories $(p<0.05)$. Mean WCTH

Table 1

Mean values, standard deviation (SD), minimum and maximum values and percentiles 5 (p5) and 90 (p90) of waist circumference and waist circumference/ height by sex and age among adolescents from the Kaingáng Indigenous Territories, Rio Grande do Sul State, Brazil, 2008.

\begin{tabular}{|c|c|c|c|c|c|c|c|c|}
\hline & $\mathrm{n}$ & Mean & SD & Minimum & Maximum & p5 & p90 & $p$-value * \\
\hline \multicolumn{9}{|l|}{ Waist circumference $(\mathrm{cm})$} \\
\hline Boys (years) & & & & & & & & $<0.001$ \\
\hline Total & 931 & 68.12 & 7.59 & 51.00 & 115.00 & 58.41 & 77.15 & \\
\hline $10-11$ & 360 & 64.45 & 6.72 & 51.00 & 101.25 & 56.75 & 72.10 & \\
\hline $12-13$ & 289 & 67.77 & 5.89 & 56.80 & 92.60 & 60.35 & 75.25 & \\
\hline $14-15$ & 173 & 71.57 & 6.96 & 61.25 & 102.45 & 63.47 & 77.99 & \\
\hline $16-19$ & 109 & 75.64 & 7.38 & 60.80 & 115.00 & 67.65 & 81.90 & \\
\hline Girls (years) & & & & & & & & $<0.001$ \\
\hline Total & 872 & 71.66 & 9.22 & 54.40 & 121.90 & 58.93 & 83.95 & \\
\hline $10-11$ & 361 & 66.45 & 7.03 & 54.40 & 97.00 & 57.25 & 76.17 & \\
\hline $12-13$ & 282 & 72.58 & 7.80 & 54.65 & 105.25 & 61.81 & 83.13 & \\
\hline $14-15$ & 163 & 77.77 & 8.29 & 56.90 & 103.00 & 65.02 & 88.25 & \\
\hline $16-19$ & 66 & 81.10 & 9.65 & 65.35 & 121.90 & 67.72 & 93.08 & \\
\hline Boys and girls (years) & & & & & & & & $<0.001$ \\
\hline Total & 1,803 & 69.83 & 8.60 & 51.00 & 121.90 & 58.56 & 80.88 & \\
\hline $10-11$ & 721 & 65.45 & 6.95 & 51.00 & 101.25 & 57.20 & 74.69 & \\
\hline $12-13$ & 571 & 70.15 & 7.30 & 54.65 & 105.25 & 60.53 & 80.08 & \\
\hline $14-15$ & 336 & 74.58 & 8.23 & 56.90 & 103.00 & 64.00 & 86.23 & \\
\hline $16-19$ & 175 & 77.70 & 8.70 & 60.80 & 121.90 & 67.74 & 87.48 & \\
\hline \multicolumn{9}{|c|}{ Waist circumference/height } \\
\hline Boys (years) & & & & & & & & $<0.001$ \\
\hline Total & 931 & 0.47 & 0.04 & 0.39 & 0.70 & 0.42 & 0.51 & \\
\hline $10-11$ & 360 & 0.47 & 0.04 & 0.41 & 0.68 & 0.42 & 0.52 & \\
\hline $12-13$ & 289 & 0.46 & 0.04 & 0.39 & 0.62 & 0.42 & 0.52 & \\
\hline $14-15$ & 173 & 0.46 & 0.04 & 0.40 & 0.66 & 0.41 & 0.49 & \\
\hline $16-19$ & 109 & 0.46 & 0.04 & 0.40 & 0.70 & 0.41 & 0.50 & \\
\hline Girls (years) & & & & & & & & $<0.001$ \\
\hline Total & 872 & 0.49 & 0.05 & 0.40 & 0.77 & 0.43 & 0.56 & \\
\hline $10-11$ & 361 & 0.48 & 0.04 & 0.40 & 0.65 & 0.43 & 0.54 & \\
\hline $12-13$ & 282 & 0.49 & 0.05 & 0.40 & 0.69 & 0.43 & 0.55 & \\
\hline $14-15$ & 163 & 0.51 & 0.05 & 0.41 & 0.68 & 0.43 & 0.58 & \\
\hline $16-19$ & 66 & 0.53 & 0.06 & 0.43 & 0.77 & 0.45 & 0.60 & \\
\hline Boys and girls (years) & & & & & & & & 0.001 \\
\hline Total & 1,803 & 0.48 & 0.05 & 0.39 & 0.77 & 0.42 & 0.55 & \\
\hline $10-11$ & 721 & 0.48 & 0.04 & 0.40 & 0.68 & 0.43 & 0.53 & \\
\hline $12-13$ & 571 & 0.48 & 0.04 & 0.39 & 0.69 & 0.42 & 0.54 & \\
\hline $14-15$ & 336 & 0.48 & 0.06 & 0.40 & 0.68 & 0.42 & 0.57 & \\
\hline $16-19$ & 175 & 0.49 & 0.06 & 0.40 & 0.77 & 0.42 & 0.57 & \\
\hline
\end{tabular}

Note: All mean differences were statistically significant $(p<0.05)$ between sexes for all age categories (Student's t-test for unequal variances between groups), * $p$-value for comparing means among the different age categories (ANOVA). 
increased with age for girls $(\mathrm{p}<0.001)$, with values above 0.5 in the age categories 14-15 and 1619 years. Conversely, WCTH tended to decrease with age among boys.

As expected, mean WC and WCTH values were significantly higher among adolescentes presenting BMI-for-age $>2$ z-scores when compared to normal-weight ones. Normal-weight girls showed higher WC and WCTH mean values than normal-weight boys throughout all age categories. Furthermore, in normal-weight girls aged 16-19 years the WCTH ratio was greater than 0.5 , in contrast to normal-weight boys where the WCTH ratio was less than 0.5 in all age categories. Finally, in boys and girls with BMI-for-age $>2 \mathrm{z}$-scores, WCTH values were greater than 0.5 throughout all age categories, reaching 0.62 in boys and 0.68 in girls in the $16-19$ years age category (Table 2).

The proportion of WCTH values > 0.5 was significantly different between all age categories. In girls, the prevalence of WCTH $>0.5$ almost tripled between the 10-11 and 16-19 years age categories, increasing from $24.93 \%$ to $72.73 \%$, respectively. Overall, the prevalence of high WCTH values was lower among boys, regardless of age category (Table 3).

With respect to WC and BMI-for-age values, a moderate positive correlation $(r=0.75, p<0.001)$ was observed for the entire study population. A similar correlation was observed for WCTH and BMI-for-age values $(r=0.79, p<0.001)$. When the data was stratified by sex, a stronger positive correlation was observed between WC and BMI-forage, and WCTH and BMI-for-age in girls $(\mathrm{r}=0.79$ and 0.80 , respectively; $\mathrm{p}<0.001$ for both). Among boys, this correlation was weaker, but was also statistically significant $(r=0.68$ for WC and BMIfor-age, and $\mathrm{r}=0.76$ for WCTH and BMI-for-age; $\mathrm{p}<0.001$ for both) (data not shown).

\section{Discussion}

For indigenous adolescents enrolled in schools in Kaingáng ITs in the State of Rio Grande do Sul, mean WC and WCTH values were greater among female adolescents than in their male counterparts. The prevalence of WCTH values $>0.5$ was also high. For all age categories, the prevalence of WCTH values > 0.5 was higher in female adolescents. As expected, mean WC and WCTH values were significantly higher for adolescents with BMI-for-age $>2 \mathrm{z}$-scores when compared to adolescents with normal weight. Moreover, a positive correlation between WC and BMI-for-age and WCTH and BMI-for-age was observed among both sexes.
Few studies have evaluated the nutritional status of indigenous adolescents and even fewer have evaluated WC, limiting comparative analyses with studies conducted with non-indigenous populations. This lack of health and nutrition information for indigenous peoples in Brazil affects broader planning, implementation and evaluation of health interventions targeted at this segment of the population 35. A clear example of this neglect is the fact that Brazilian indigenous individuals have not been included in national surveys on health and nutrition, while the rest of the population has been evaluated in such surveys since the 1970s 2 . In fact, it was only in 2008 that a specific study of the health and nutrition status of the Brazilian indigenous population was conducted through the First National Survey on Nutrition and Health of Indigenous Peoples ${ }^{36}$.

Nevertheless, specific national studies with different ethnic groups provide evidence that overweight and obesity are emerging problems among indigenous population and show that dietary and nutritional patterns are in transition and that these changes may be happening even more rapidly than among the non-indigenous population 4,37,38,39,40. Data from the First National Survey on Health and Nutrition of Indigenous Peoples show that when the prevalence of child malnutrition and anaemia becomes alarming, chronic non-communicable diseases are already a reality 36 . The survey also revealed a worrying scenario in which obesity, hypertension and changes in glucose levels have occurred with high frequencies amongst women of reproductive age. However, the national survey assessed indigenous children aged zero to five years and women aged 14 to 49 years 36 , as opposed to the current study that evaluated adolescents of both sexes aged 10 through 19 years. Comparisons of the results of the present study with the national survey are therefore very limited.

Studies indicate that the Kaingáng people face serious health care problems. Research also highlights a complex epidemiological profile for this population, in which health problems as diverse as respiratory and parasitic infections coexist at relevant magnitudes 41,42 with chronic noncommunicable diseases, such as type 2 diabetes, hypertension 43 and even alcoholism 44 . A critical factor that may partially explain the results obtained in the present study are dietary changes in the Kaingáng population over time. The traditional dietary patterns of the Kaingáng, based on hunting and gathering, fishing and agriculture 45 have changed markedly; today, this population relies on the acquisition of commercial foods at markets in nearby towns and donated "food bas- 
Mean values and standard deviation (SD) of waist circumference and waist circumference/height according to sex, age and nutritional status among adolescents from the Kaingáng Indigenous Territories, Rio Grande do Sul State, Brazil, 2008.

\begin{tabular}{|c|c|c|c|c|c|c|c|c|c|}
\hline & \multicolumn{4}{|c|}{ BMI/age -2/2 z-scores } & \multicolumn{4}{|c|}{ BMI/age > 2 z-scores } & \multirow[t]{2}{*}{$\mathrm{p}$-value * } \\
\hline & $\mathbf{n}$ & Mean & SD & $\mathrm{p}$-value ** & $\mathbf{n}$ & Mean & SD & $\mathrm{p}$-value ** & \\
\hline \multicolumn{10}{|l|}{ Waist circumference $(\mathrm{cm})$} \\
\hline Boys (years) & & & & $<0.001$ & & & & $<0.001$ & \\
\hline Total & 873 & 67.06 & 5.99 & & 46 & 86.07 & 9.55 & & 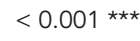 \\
\hline $10-11$ & 332 & 63.07 & 4.44 & & 27 & 81.49 & 6.86 & & $<0.001 \#$ \\
\hline $12-13$ & 280 & 67.19 & 4.92 & & 9 & 85.72 & 5.63 & & $<0.001 \#$ \\
\hline $14-15$ & 165 & 70.55 & 4.67 & & 7 & 96.61 & 4.96 & & 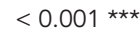 \\
\hline $16-19$ & 96 & 74.41 & 4.57 & & 3 & 103.78 & 9.89 & & $0.017 * \star \star$ \\
\hline Girls (years) & & & & $<0.001$ & & & & $<0.001$ & \\
\hline Total & 792 & 70.26 * & 7.87 & & 75 & 86.23 & 9.16 & & 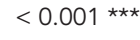 \\
\hline $10-11$ & 329 & 65.13 * & 5.57 & & 31 & 80.53 & 5.55 & & $<0.001 \#$ \\
\hline $12-13$ & 257 & 71.20 * & 6.41 & & 25 & 86.76 & 6.66 & & $<0.001 \#$ \\
\hline $14-15$ & 146 & 76.33 * & 6.67 & & 15 & 92.30 & 6.64 & & $<0.001 \#$ \\
\hline $16-19$ & 60 & 79.52 * & 6.47 & & 4 & 104.40 & 15.48 & & 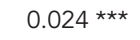 \\
\hline Boys and girls (years) & & & & $<0.001$ & & & & $<0.001$ & \\
\hline Total & 1,665 & 68.58 & 7.13 & & 121 & 86.17 & 9.27 & & $<0.001 * \star \star *$ \\
\hline $10-11$ & 661 & 64.10 & 5.13 & & 58 & 80.97 & 6.16 & & $<0.001$ *** \\
\hline $12-13$ & 537 & 69.11 & 6.02 & & 34 & 86.48 & 6.34 & & $<0.001 \#$ \\
\hline $14-15$ & 311 & 73.26 & 6.38 & & 22 & 93.67 & 6.37 & & $<0.001 \#$ \\
\hline $16-19$ & 156 & 76.38 & 5.91 & & 7 & 104.14 & 12.35 & & $<0.001 * \star \star$ \\
\hline \multicolumn{10}{|c|}{ Waist circumference/height } \\
\hline Boys (years) & & & & $<0.001$ & & & & 0.048 & \\
\hline Total & 873 & 0.46 & 0.03 & & 46 & 0.58 & 0.05 & & 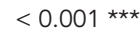 \\
\hline $10-11$ & 332 & 0.46 & 0.03 & & 27 & 0.57 & 0.05 & & $<0.001 \#$ \\
\hline $12-13$ & 280 & 0.46 & 0.03 & & 9 & 0.57 & 0.04 & & $<0.001 \#$ \\
\hline $14-15$ & 165 & 0.45 & 0.03 & & 7 & 0.62 & 0.03 & & 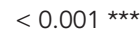 \\
\hline $16-19$ & 96 & 0.46 & 0.03 & & 3 & 0.62 & 0.07 & & 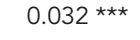 \\
\hline Girls (years) & & & & $<0.001$ & & & & $<0.001$ & \\
\hline Total & 792 & 0.49 \#\# & 0.04 & & 75 & 0.59 & 0.05 & & $<0.001^{\star \star \star *}$ \\
\hline $10-11$ & 329 & $0.47 \#$ & 0.03 & & 31 & 0.57 & 0.03 & & $<0.001 \#$ \\
\hline $12-13$ & 257 & $0.48 \# \#$ & 0.04 & & 25 & 0.58 & 0.04 & & $<0.001 \#$ \\
\hline $14-15$ & 146 & $0.50 \# \#$ & 0.04 & & 15 & 0.61 & 0.04 & & $<0.001 \#$ \\
\hline $16-19$ & 60 & $0.52 \# \#$ & 0.04 & & 4 & 0.68 & 0.10 & & $0.024 * \star \star$ \\
\hline Boys and girls (years) & & & & $<0.001$ & & & & $<0.001$ & \\
\hline Total & 1,665 & 0.47 & 0.04 & & 121 & 0.59 & 0.05 & & $<0.001$ *** \\
\hline $10-11$ & 661 & 0.47 & 0.03 & & 58 & 0.57 & 0.04 & & $<0.001$ *** \\
\hline $12-13$ & 537 & 0.47 & 0.04 & & 34 & 0.58 & 0.04 & & $<0.001 \#$ \\
\hline $14-15$ & 311 & 0.48 & 0.05 & & 22 & 0.61 & 0.04 & & $<0.001 \#$ \\
\hline $16-19$ & 156 & 0.48 & 0.05 & & 7 & 0.65 & 0.09 & & $0.001 * \star *$ \\
\hline
\end{tabular}

BMI: body mass index.

* $\mathrm{p}$-value for comparison of means between BMI/age categories (Student's t-test);

** $p$-value for comparison of means among different age categories (ANOVA);

*** Student's t-test for unequal variances between sexes;

\# Student's t-test for equal variances between sexes;

\#\# Mean statistically significant values higher for girls when compared to boys from the same age category.

kets". Furthermore, available data points to a fat and carbohydrate-rich diet 37,40 .

The mean WC values for both sexes described in this study were lower than those found in a study conducted between 1999 and 2004 among non-indigenous adolescents aged 12 to 17 years in the United States $(78.9 \mathrm{~cm}$ for girls and $79.8 \mathrm{~cm}$ for boys) 33 . However, when data from our study is compared with data from studies of non-indigenous Brazilian adolescents, mean WC values are similar or higher. Mean WC values similar to those found in our study were observed in a 
Prevalence of elevated values of waist circumference/height by sex and age among adolescents in the Kaingáng Indigenous Territories, Rio Grande do Sul State, Brazil, 2008.

\begin{tabular}{|c|c|c|c|c|}
\hline & \multirow[t]{2}{*}{$\mathbf{N}$} & \multicolumn{3}{|c|}{ Waist circumference/height $(>0,5)$} \\
\hline & & $\mathbf{n}$ & $\%$ & $\mathrm{p}$-value * \\
\hline Boys (years) & & & & 0.009 \\
\hline Total & 931 & 133 & 14.29 & \\
\hline $10-11$ & 360 & 68 & 18.89 & \\
\hline $12-13$ & 289 & 38 & 13.15 & \\
\hline $14-15$ & 173 & 16 & 9.25 & \\
\hline $16-19$ & 109 & 11 & 10.09 & \\
\hline Girls (years) & & & & $<0.001$ \\
\hline Total & 872 & 330 & 37.84 & \\
\hline $10-11$ & 361 & 90 & 24.93 & \\
\hline $12-13$ & 282 & 101 & 35.82 & \\
\hline $14-15$ & 163 & 91 & 55.83 & \\
\hline $16-19$ & 66 & 48 & 72.73 & \\
\hline Boys and girls (years) & & & & $<0.001$ \\
\hline Total & 1,803 & 463 & 25.68 & \\
\hline $10-11$ & 721 & 158 & 21.91 & \\
\hline $12-13$ & 571 & 139 & 24.34 & \\
\hline $14-15$ & 336 & 107 & 31.85 & \\
\hline $16-19$ & 175 & 59 & 33.71 & \\
\hline
\end{tabular}

Note: All differences in prevalence were statistically significant $(p<0.05)$ between sexes for all age categories (two-sample

test of proportion)

* $p$-value from chi-square test for comparison of proportions between the different age categories.

study in the State of Pernambuco 46 of adolescents aged 14 to 19 years and in a study which investigated adolescents from three Brazilian cities 47 . In a study of adolescents aged between 10 and 17 years in the city of Londrina in the State of Paraná, mean WC values for male adolescents were higher $(72.4 \mathrm{~cm})$ than the present study, while among female adolescents they were lower $(67.5 \mathrm{~cm}) 48$.

Mean WCTH values identified in the present study are consistent with those observed in the above mentioned study of North American adolescents ( 0.47 among boys and 0.49 for girls) 33 . Work conducted by Ribeiro et al. 47 among adolescents in three Brazilian state capitals, showed lower (0.45) mean WCTH values than those observed for Kaingáng adolescents. The prevalence of WCTH values $>0.5$ in male adolescents was lower than the percentage indicated by Li et al. 33 from a study of North American adolescents of the same sex (28.8\%). However, for female adolescents, the percentages were similar in both studies. In Recife, Brazil, the prevalence of WCTH values $>0.5$ among adolescents aged 10 to 14 years was lower (12.6\%) than in the present study 49 .
Strong positive correlations between the anthropometric indicators measured in this study (BMI-for-age, WC and WCTH) have also been described by other authors 13,49. The use of more than one indicator gives additional information, especially regarding the risk of co-morbidities related to excessive weight and particularly the association with central adiposity. In line with this idea, a study by Jansen et al. 50 showed that for adolescents diagnosed as overweight using BMIfor-age, those with a concomitant high WC value were twice as likely to have high levels of triglycerides and insulin and metabolic syndrome when compared with the overweight group without abdominal obesity 50 . Given this evidence, the use of WC together with BMI to diagnose obesity in adolescents and to screen patients at risk for comorbidities, particularly cardiovascular disease, has been recommended 50 .

Our study design made it possible to evaluate more than $70 \%$ of the adolescents enrolled in schools in the Kaingáng ITs of Rio Grande do Sul. However, care should still be taken when extrapolating these results to all Kaingáng children and adolescents from Rio Grande do Sul, as the 
study included only individuals enrolled in the IT schools and is therefore representative of only this fraction of the Kaingáng population. Furthermore, the low height values presented by this population may have led to an overestimation of prevalence of high WCTH and should therefore be interpreted with caution. For adolescents, height may not depend exclusively on the nutritional status, living conditions or environment that may differ between populations 2 . It should be noted that the lack of comparative WCTH data on indigenous adolescents hinders further comparisons and conclusions. Another important limitation of this study is the lack of information on the sexual maturation stage of the adolescents studied, which also restricts the interpretation of the results. Furthermore, due the lack of data on specific metabolic diseases, it was not possible to perform correlation analysis between WC and WCTH and meta- bolic diseases as suggested in previous studies in the area $51,52,53$.

The anthropometric nutritional assessment of adolescents can also be a challenging task due to the issues regarding the cut-off points and reference standards used. To the authors' best knowledge, the present study is the largest to assess the distribution of WC and WCTH values among students of a single indigenous ethnic group in Brazil. Considering the importance of WC and WCTH values in a more sensitive diagnosis of obesity, additional studies assessing these indicators in different indigenous populations are sorely needed. The anthropometric profile of WC and WCTH among Kaingáng adolescents in the schools of Rio Grande do Sul presented in this study may be result of dietary and nutritional transitions among these individuals, revealing worrying prospects for the development of chronic non-communicable diseases.

\section{Resumo}

Os objetivos do estudo foram descrever a distribuição das medidas de circunferência de cintura (CC) e CCl estatura (CC/E) para adolescentes indígenas Kaingáng; estimar a prevalência de valores elevados para CC/E; $\boldsymbol{e}$ avaliar a correlação entre CC e CC/E com o IMC/idade. Um total de 1.803 adolescentes indígenas foi avaliado no estudo seccional de base escolar. Foram considerados elevados valores de CC/E superiores a 0,5. Observaramse maiores valores médios de CC e CC/E para meninas, em todas as faixas etárias. Valores de CC/E $>0,5$ foram encontrados em 25,6\% dos adolescentes. Valores médios de CC e CC/E foram significativamente maiores para os adolescentes com IMC/idade $>2 z$-scores, em comparação aos eutróficos. Os coeficientes de correlações entre CC e CC/E com o IMC/idade foram: meninos: $r=0,68$ e 0,76 , respectivamente, e meninas: $r=0,79$ e 0,80 , respec tivamente. Destaca-se proeminência de valores médios elevados de CC e CC/E e prevalências expressivas de obesidade abdominal.

Antropometria; Obesidade Abdominal; População Indígena; Saúde de Populações Indígenas

\section{Contributors}

T. G. Castro participated in drafting the study, data collection, analysis and writing of the manuscript. L. A. Barufaldi contributed to gathering and recording information, analyzing data and writing the manuscript. M. M. Schlüssel, W. L. Conde, M. S. Leite and I. Schuch participated in study design and writing of the manuscript.

\section{Acknowledgements}

We would like to thank all the Kaingáng living in Rio Grande do Sul for their receptivity; the National Indigenous Foundation of Passo Fundo (Fundação Nacional do Índio de Passo Fundo) for supporting the field research team; Carmen Dutra, Ana Paula Campos, Cristiane dos Santos, Cristiane da Silva, Cynthia Garcia, Joyce Silveira and Tania Machado for their efficiency, enthusiasm and competence. 


\section{References}

1. Wang Y, Monteiro CA, Popkin BM. Trends of obesity and underweight in older children and adolescents in the United States, Brazil, China, and Russia. Am J Clin Nutr 2002; 75:971-7.

2. Leite MS, Santos RV, Gugelmim SA, Coimbra Jr. CEA. Crescimento físico e perfil nutricional da população indígena Xavánte de Sangradouro-Volta Grande, Mato Grosso, Brasil. Cad Saúde Pública 2006; 22:265-76.

3. Sampei MA, Cano EN, Fagundes U, Lima EES, Rodrigues D, Sigulem DM, et al. Avaliação antropométrica de adolescentes Kamayurá, povo indígena do Alto Xingu, Brasil Central (2000-2001). Cad Saúde Pública 2007; 23:1443-53.

4. Castro TG, Schuch I, Conde WL, Veiga J, Leite MS, Dutra CLC, et al. Estado nutricional dos indígenas Kaingáng matriculados em escolas indígenas do estado do Rio Grande do Sul, Brasil. Cad Saúde Pública 2010; 26:1766-76.

5. Carmona-Fonseca J, Correa AMB, Alcaraz GLM. Población, alimentación y estado nutricional entre los tules (kunas) del resguardo Caimán Nuevo (Turbo y Necoclí; Antioquia, Colombia), 20032004. Iatreia 2005; 18:259-78.

6. Santos RV, Coimbra Jr. CEA. Socioeconomic differentiation and body morphology in the Surui of Southwestern Amazonia. Curr Anthropol 1996; 37:851-6.

7. Menegolla IA, Drachler ML, Rodrigues IH, Schwingel LR, Scapinello E, Pedroso MB, et al. Estado nutricional e fatores associados à estatura de crianças da Terra Indígena Guarita, Sul do Brasil. Cad Saúde Pública 2006; 22:395-406.

8. Ferreira AA, Welch JR, Santos RV, Gugelmin AS, Coimbra Jr. CEA. Nutritional status and growth of indigenous Xavante children, Central Brazil. Nutr J 2012; 11:3.

9. De Onis M, Onyango AW, Borghi E, Siyam A, Nishida C, Siekmanna J. Development of a WHO growth reference for school-aged children and adolescents. Bull World Health Organ 2007; 85:660-7.

10. Tomkins A. Measuring obesity in children: what standards to use? J Pediatr 2006; 82:246-8.

11. Gomes FS, Anjos LA, Vasconcellos MTL. Antropometria como ferramenta de avaliação do estado nutricional coletivo de adolescentes. Rev Nutr 2010; 23:591-605.

12. Gugelmin SA, Santos RV. Uso do índice de massa corporal na avaliação do estado nutricional de adultos indígenas Xavánte, Terra Indígena Sangradouro-Volta Grande, Mato Grosso, Brasil. Cad Saúde Pública 2006; 22:1865-72.

13. Giugliano R, Melo ALP. Diagnóstico de sobrepeso e obesidade em escolares: utilização do índice de massa corporal segundo padrão internacional. J Pediatr (Rio J.) 2004; 80:129-34.

14. Garnett SP, Baur LA, Srinivasan S, Lee JW, Cowell CT. Body mass index and waist circumference in midchilhood and adverse cardiovascular disease risk clustering in adolescence. Am J Clin Nutr 2007; 86:549-55.
15. Must A, Dallal GE, Dietz WH. Reference data for obesity: 85th and 95th percentiles of body mass index (wt/ht2) and tríceps skinfold thickness. Am J Clin Nutr 1991; 53:839-46.

16. Cole TJ, Bellizzi MC, Flegal KM, Dietz WH. Establishing a standard definition for child overweight and obesity worldwide: international survey. BMJ 2000; 320:1240-2

17. Conde WL, Monteiro CA. Body mass index cutoff points for evaluation of nutritional status in Brazilian children and adolescents. J Pediatr 2006; 82:266-72.

18. Despres JP, Moorjani S, Lupien PJ, Tremblay A, Nadeau A, Bouchard C. Regional distribution of body fat, plasma lipoproteins, and cardiovascular disease. Arteriosclerosis 1990; 10:497-511.

19. Lee CMY, Huxley RR, Wildman RP, Woodward M. Indices of abdominal obesity are better discriminators of cardiovascular risk factors than BMI: a meta-analysis. J Clin Epidemiol 2008; 61:646-53.

20. Maffeis C, Pietrobelli A, Grezzani A, Provera S, Tato L. Waist circumference and cardiovascular risk factors in prepubertal children. Obes Res 2001; 9: 179-87.

21. Esmaillzadeh A, Mirmiran P, Azizi F. Clustering of metabolic abnormalities in adolescents with the hypertriglyceridemic waist phenotype. Am J Clin Nutr 2006; 83:36-46.

22. Maffeis C, Banzato C, Talamin G; Obesity Study Group of the Italian Society of Pediatric Endocrinology and Diabetology. Waist-to-height ratio, a useful index to identify high metabolic risk in overweight children. J Pediatr 2008; 152:207-13.

23. Must A, Hollander SA, Economos CD. Childhood obesity: a growing public health concern. Expert Rev Endocrinol Metab 2006; 1:233-54.

24. Haun DR, Pitanga FJG, Lessa I. Waist/height ratio compared with other anthropometric indicators of obesity as a predictor of high coronary risk. Rev Assoc Med Bras (1992) 2009; 55:705-11.

25. Li M, McDermot RA. Using anthropometric indices to predict cardio-metabolic risk factors in Aus ralian indigenous populations. Diabetes Res Clin Pract 2010; 87:401-6.

26. Cardoso AM, Mattos IE, Koifman RJ. Prevalência de fatores de risco para doenças cardiovasculares na população Guaraní-Mbyá do Estado do Rio de Janeiro. Cad Saúde Pública 2001; 17:345-54.

27. Gimeno SG, Rodrigues D, Pagliaro H, Cano EM, Lima EES, Baruzzi RG. Perfil metabólico e antropométrico de índios Aruák: Mehináku, Waurá e Yawalapití, Alto Xingu, Brasil Central, 2000/2002. Cad Saúde Pública 2007; 23:1946-54.

28. World Health Organization. Necesidades de la salud de los adolescentes. Geneva: World Health Organization; 1977. (WHO Technical Report Series, 609).

29. Ricardo CA. Povos indígenas no Brasil 1996/2000. São Paulo: Instituto Socioambiental; 2000 
30. World Health Organization. Physical status: the use and interpretation of anthropometry. Geneva: World Health Organization; 1995 (WHO Technical Report Series, 854).

31. World Health Organization. Measuring obesity: classification and description of anthropometric data. Copenhagen: World Health Organization; 1989.

32. McCarthy HD, Ashwell M. A study of central fatness using waist-to-height ratios in UK children and adolescents over two decades supports the simple message - "keep your waist circumference to less than half your height". Int J Obes Relat Metab Disord 2006; 30:988-92.

33. Li C, Ford ES, Mokdad AH, Cook S. Recent trends in waist circumference and waist-height ratio among US children and adolescents. Pediatrics 2006; 118:1390-8.

34. Fundação Nacional do Índio. Instrução normativa no. 01/PRESI de 29 de novembro de 1995. Brasília: Fundação Nacional do Índio; 1995.

35. Coimbra Jr. CEA, Santos RV. Saúde, minorias e desigualdade:algumas teias de inter-relações, com ênfase nos povos indígenas no Brasil. Ciênc Saúde Coletiva 2000; 5:125-32.

36. Associação Brasileira de Pós-graduação em Saúde Coletiva. Boletim ABRASCO 105 2010; Ano XXVII.

37. Schuch I. Perfil socioeconômico e alimentar das famílias indígenas Kaingang do Guarita RS [Dissertação de Mestrado]. Campinas: Faculdade de Engenharia de Alimentos, Universidade Estadual de Campinas; 2001.

38. Gugelmin AS, Santos RV. Ecologia humana e antropometria nutricional de adultos Xavánte, Mato Grosso, Brasil. Cad Saúde Pública 2001; 17:313-22.

39. Leite MS, Santos RV, Coimbra Jr. CEA. Sazonalidade e estado nutricional de populações indígenas: o caso Wari', Rondônia, Brasil. Cad Saúde Pública 2007; 23:2631-42.

40. Kühl AM, Corso ACT, Leite MS, Bastos JL. Perfil nutricional e fatores associados à ocorrência de desnutrição entre crianças indígenas Kaingáng da Terra Indígena de Mangueirinha, Paraná, Brasil. Cad Saúde Pública 2009; 25:409-20.

41. Hökerberg YHM, Duchiade MP, Barcellos CC. Organização e qualidade da assistência à saúde dos índios Kaingáng do Rio Grande do Sul, Brasil. Cad Saúde Pública 2001; 17:261-72.

42. Gilio J, Mioranza SL, Takizawa MGMH. Parasitismo intestinal em índios da reserva indígena de Rio das Cobras. Rev Bras Anal Clin 2006; 38:193-5.

43. Portela-García S. Diabetes e hipertensão arterial entre os indígenas Kaingang da Aldeia Sede, Terra Indigena Xapecó (SC): práticas de autoatenção em um contexto de intermedicalidade [Dissertação de Mestrado]. Florianópolis: Programa de Pós-Graduação em Antropologia Social, Universidade Federal de Santa Catarina; 2010.
44. Ghiggi Jr. A. Estudo etnográfico sobre alcoolização entre os índios Kaingang da Terra Indígena Xapecó: das dimensões construtivas à perturbação [Dissertação de Mestrado]. Florianópolis: Programa de Pós-Graduação em Antropologia Social, Universidade Federal de Santa Catarina, 2010.

45. Veiga J. Aspectos fundamentais da cultura Kaingáng. São Paulo: Editora Curt Nimuendajú; 2006.

46. Cavalcanti CBS, Barros MVG, Meneses AL, Santos CM, Azevedo AMP, Guimarães FJSP. Obesidade abdominal em adolescentes: prevalência e associação com atividade física e hábitos alimentares. Arq Bras Cardiol 2010; 94:371-7.

47. Ribeiro RC, Coutinho M, Bramorski MA, Giuliano IC, Pavan J. Association of the waist-to-height ratio with cardiovascular risk factors in children and adolescents: The Three Cities Heart Study. Int J Prev Med 2010; 1:39-49.

48. Christofaro DGD, Ritti-Dias RM, Fernandes RA, Polito MD, Andrade SM, Cardoso JR, et al. Detecção de hipertensão arterial em adolescentes através de marcadores gerais e adiposidade abdominal. Arq Bras Cardiol 2011; 96:465-70.

49. Pinto ICS, Arruda IKG, Diniz AS, Cavalcanti AMTS. Prevalência de excesso de peso e obesidade abdominal, segundo parâmetros antropométricos, e associação com maturação sexual em adolescentes escolares. Cad Saúde Pública 2010; 26:1727-37.

50. Janssen I, Katzmarzyk PT, Srinivasan SR, Chen W, Malina RM, Bouchard C, et al. Combined influence of body mass index and waist circumference on coronary artery risk factors among children and adolescents. Pediatrics 2005; 115:1623-30.

51. Picon PX, Leitão CB, Gerchman F, Azevedo MJ, Silveiro SP, Gross JL, et al. Medida da cintura e razão cintura/quadril e identificação de situações de risco cardiovascular: estudo multicêntrico em pacientes com diabetes melito tipo 2. Arq Bras Endocrinol Metab 2007; 51:443-9.

52. Lunardi CC, Petroski EL. Índice de massa corporal, circunferência da cintura e dobra cutânea triciptal na predição de alterações lipídicas em crianças com 11 anos de idade. Arq Bras Endocrinol Metab 2008; 52:1009-14.

53. Matos LN, Giorelli GV, Dias CB. Correlation of anthropometric indicators for identifying insulin sensitivity and resistance. São Paulo Med J 2011; 129:30-5

Submitted 06/Feb/2012

Final version resubmitted on 19/Jul/2012

Approved on 23/Jul/2012 